\title{
PERENCANAAN TENAGA KERJA DAERAH KOTA PADANG 2014-2018
}

\author{
Sofyardi \\ Jurusan Ilmu Ekonomi Universitas Andalas \\ Renny Maisyarah \\ Fakultas Ekonomi dan Bisnis Universitas Pembangunan PancaBudi \\ Email: sofyardi123@yahoo.co.id
}

\begin{abstract}
With the ever-increasing number of people and the labor force on the one hand, and the limited employment opportunities on the other hand have resulted in an imbalance between supply and labor demand. If this problem is not resolved successfully, it can have adverse impacts in the social, economic, political, and security fields. The handling of employment issues can only be successful if based on good manpower planning. Therefore, the immediate problem faced is how to find the right balance between the growth of the labor force and the employment opportunities in the development process. It is therefore necessary to projection the provision of manpower in relation to the business of creating employment opportunities in the future.
\end{abstract}

Key words: Projection of Labor Supply

\section{PENDAHULUAN}

ondisi umum tenaga kerja di kota Padang saat ini, sama seperti halnya dengan Indonesia secara keseluruhan, sangat kompleks dan multi-dimensi. Masalah tersebut tidak berdiri sendiri tetapi saling berkaitan dengan aspek lain seperti jumlah penduduk yang besar dan laju pertumbuhan yang tinggi, pesebaran penduduk yang tidak merata, struktur umur muda, dan kualitas yang rendah. Sementara itu perluasan kesempatan kerja masih belum memadai.

Hasil laporan Badan Pusat Statistik (BPS) mencatat bahwa penduduk Kota Padang bertambah dari 875.750 jiwa pada tahun 2009 menjadi 876.670 jiwa pada tahun 2013, dengan laju pertumbuhan 0,03 persen per tahun. Pada tingkat pertumbuhan tersebut, diperkirakan penduduk Kota Padang akan mencapai lebih dari 877 ribu jiwa pada tahun 2018. Sejalan dengan pertumbuhan penduduk tersebut, angkatan kerja meningkat dari 353.238 orang pada tahun 2009 menjadi 361.071 orang pada tahun 2013, dan akan QE J ournal | Vol.06 - N 0.03 December 2017 - 222 
mencapai sekitar 372 ribu orang pada tahun 2018. Dari 372 ribu angkatan kerja tersebut, sebagian besar merupakan angkatan kerja muda yang berumur $15-24$ tahun.

Data hasil hasil laporan Badan Pusat Statistik (BPS) mencatat bahwa pada tahun 2013 jumlah penduduk usia remaja 0 - 14 tahun di Kota Padang mencapai 247.939 orang, atau sekitar 28,28 persen dari total penduduk. Angka ini meningkat sebesar 3.106 orang dibanding tahun 2009 dengan laju pertumbuhan rata-rata sebesar 0,32 persen per tahun. Peningkatan jumlah penduduk usia $0-14$ tahun ini memberikan tekanan yang kuat pada sisi penawaran tenaga kerja di tahun - tahun mendatang.

Kota Padang juga menghadapi persoalan pengangguran yang cukup serius. Tingkat pengangguran terbuka sedikit menurun dari 15,86 persen pada tahun 2009 menjadi 13,99 persen pada tahun 2013. Jumlah pengangguran terbuka pada tahun 2013 mencapai 50.505 orang. Selain karena ketidakseimbangan antara penawaran dan permintaan tenaga kerja, tingginya tingkat pengangguran di Kota Padang juga disebabkan oleh persoalan - persoalan yang dijumpai di pasar kerja, yaitu ketidak sesuaian antara keahlian yang dimiliki oleh pencari kerja dengan kebutuhan pasar kerja. Sistem pendidikan dan latihan belum mampu menghasilkan tenaga kerja yang ahli dan terampil sesuai dengan kebutuhan pasar kerja. Akibatnya disatu pihak terdapat kelebihan tenaga kerja terdidik, dipihak lain dirasakan adanya kekurangan tenaga terdidik.

Dengan terus bertambahnya jumlah penduduk dan angkatan kerja disatu sisi, dan terbatasnya kesempatan kerja di sisi lain telah mengakibatkan ketidakseimbangan antara persedian dan kebutuhan tenaga kerja. Bila masalah ini tidak berhasil di atasi, dapat memberikan dampak yang tidak menguntungkan dibidang sosial, ekonomi, politik, dan keamanan. Penanganan masalah ketenagakerjaan hanya dapat berhasil jika didasarkan pada perencanaan tenaga kerja yang baik. Oleh karena itu, masalah yang harus segera dihadapi adalah bagaimana menemukan perimbangan yang tepat antara pertumbuhan angkatan kerja dengan kesempatan kerja dalam proses pembangunan. Untuk itu perlu dilakukan proyeksi penyediaan tenaga kerja dalam kaitannya dengan usaha penciptaan kesempatan kerja dimasa mendatang. 
Tujuan dan Manfaat Penyusunan Perencanaan Tenaga Kerja Daerah (PTKD)

Tujuan utama penyusunan perencanaan tenaga kerja daerah Kota Padang adalah untuk mendapatkan gambaran tentang perkembangan persediaan dan kebutuhan tenaga kerja selama periode 2009 - 2013. Secara lebih spesifik tujuan penyusunan perencanaan tenaga kerja daerah Kota Padang adalah :

a. Menganalisis perkembangan persediaan dan kebutuhan tenaga kerja selama periode 2009 - 2013.

b. Membuat proyeksi persediaan dan kebutuhan tenaga kerja periode $2014-2018$.

c. Membuat neraca persedian dan kebutuhan tenaga kerja.

d. Merumuskan kebijakan dan program ketenagakerjaan yang diperlukan untuk periode $2014-2018$.

\section{Manfaat Penyusunan PTKD}

Penyusunan perencanaan tenaga kerja daerah (PTKD) Kota Padang bermanfaat untuk hal-hal sebagai berikut :

a. Dapat diketahui permasalahan ketenagakerjaan Kota Padang dan alternatif kebijakan dan program yang dapat dilakukan untuk mengatasi masalah tersebut.

b. Dapat meningkatkan pendayagunaan tenaga kerja dengan dikatahuinya potensi angkatan kerja yang ada di Kota Padang, baik dari segi jumlah maupun kualitas dan potensi kebutuhan tenaga kerja diberbagai sektor ekonomi.

\section{METODE PENELITIAN}

Analisis perkembangan persediaan tenaga kerja dilakukan secara deskriptif yaitu dengan menggunakan tabel frekwensi dan tabulasi silang. Perkiraan angkatan kerja diperoleh dengan jalan mengalikan hasil proyeksi tingkat partisipasi angkatan kerja (TPAK) dengan proyeksi penduduk usia kerja (15 tahun ke atas). Sedangkan proyeksi penduduk usia kerja diperoleh dari hasil proyeksi penduduk. Dengan demikian proyeksi 
angkatan kerja diperoleh dari dua buah proyeksi, yaitu proyeksi TPAK dan proyeksi penduduk.

Data yang digunakan untuk penyusunan perencanaan Tenaga Kerja Daerah Kota Padang ini adalah data sekunder yang di publikasikan oleh Badan Pusat Statistik (BPS) dan instansi pemerintah terkait lainnya. Data publikasi BPS terutama adalah data hasil Survei Angkatan Kerja Nasional (Sakernas) dan Padang Dalam Angka 2009 - 2013. Selain itu, digunakan pula data hasil penelitian yang ada, terutama hasil temuan para ahli dibidang ketenagakerjaan.

\section{HASIL DAN PEMBAHASAN}

Proyeksi TPAK dilakukan dengan menggunakan metode ekstrapolasi tidak langsung. Metode ini didasarkan pada data persentase penduduk yang tidak aktif secara ekonomi (penduduk sekolah, mengurus rumah tangga, pensiun dan katagori lainnya) dari penduduk usia kerja. Metode ini sangat cocok diterapkan pada negara dimana TPAKnya mengalami peningkatan secara perlahan (United Nations, 1971), seperti yang dialami oleh Indonesia. Metode ekstrapolasi tidak langsung ini dapat ditulis dalam bentuk rumus berikut :

$$
\gamma=\frac{\mathbf{E}_{\mathbf{t}}^{\boldsymbol{x}}}{\mathbf{E}_{\mathrm{ta}}^{x}}
$$

dimana :

$\mathrm{A}^{x}=$ Persentase penduduk yang aktif secara ekonomi untuk umur $\chi$

$\mathrm{E}^{x}=$ Persentase penduduk yang tidak aktif secara ekonomi untuk umur $\chi$

$\mathrm{t}_{\mathrm{o}}=$ awal periode

$\mathrm{t}=$ awal periode

$\mathrm{t}_{1}=$ akhir periode proyeksi

Metode perubahan kohor (Cohor Change Rate) diterapkan guna memproyeksi penduduk sampai dengan tahun 2018. Proyeksi penduduk dengan metode ini didasarkan atas tingkat perubahan kohor penduduk dari dua sensus atau survei penduduk. Menurut Pollard dan kawan-kawan (1975), metode perubahan kohor merupakan metode proyeksi penduduk yang akurat jika kualitas data kependudukan yang tersedia cukup baik.

Kebutuhan tenaga kerja tahun 2014 - 2018 diproyeksi dengan menggunakan metode trend linier. Proyeksi ini didasarkan pada QE J ournal |Vol.06 - N 0.03 December 2017 - 225 
kecenderungan tahun 2009 - 2013. Dalam perencanaan tenaga kerja, model input-output digunakan untuk melihat pengaruh permintaan akhir efektif terhadap kesempatan kerja di berbagai sektor produksi. Pengaruh ini dapat diperkirakan ke masa-masa yang akan datang sehingga dapat dijadikan sebagai bahan pertimbangan kebijakan ketenagakerjaan.

Neraca ketegakerjaan bertujuan untuk membandingkan antara persedian dan kebutuhan tenaga kerja. Ketidaksesuaian antara persediaan dan kebutuhan tenaga kerja akan menghasilkan pengangguran. Untuk menghitung kelebihan atau kekurangan antara persediaan dan kebutuhan tenaga kerja digunakan persamaan berikut :

$$
E_{t}=S_{t}-D_{t}
$$

Dimana :

$\mathrm{S}_{\mathrm{t}} \quad=$ Persediaan tenaga kerja tahun $\mathrm{t}$

$D_{\mathrm{t}} \quad=$ Kebutuhan tenaga kerja pada tahun $\mathrm{t}$

$\mathrm{E}_{\mathrm{t}}=$ Selisih antara kebutuhan dan persediaan tenaga kerja pada tahun $\mathrm{t}$ Jika $E_{t}>0$, maka terjadi kelebihan penawaran tenaga kerja dibanding dengan permintaan, berarti terjadi pengangguran. Semakin besar $E_{t}$, semakin besar pula terjadinya pengangguran.

Dalam penyusunan perencanaan tenaga kerja ada beberapa konsep dasar yang perlu diketahui. Untuk menyamakan persepsi tentang konsep yang digunakan, maka perlu dijelaskan tentang definisi atau pengertian konsep tersebut sebagai berikut :

\section{Penduduk}

Menurut Sensus Penduduk 2010 yang dimaksud dengan penduduk adalah semua orang yang berdomisili di wilayah geografis Republik Indonesia selama 6 bulan atau lebih dan atau mereka yang berdomisili kurang dari 6 bulan tetapi bertujuan untuk menetap.

\section{Penduduk Usia Kerja (Tenaga Kerja)}

Penduduk usia kerja (tenaga kerja) dapat diartikan sebagai penduduk dalam usia tertentu yang dianggap layak dan mampu untuk bekerja. Sedangkan penduduk di luar usia kerja adalah kelompok penduduk yang dianggap belum layak dan mampu untuk bekerja. Batasan umur yang ditetapkan untuk mengelompokkan penduduk dalam usia kerja maupun 
diluar usia kerja yang dilakukan oleh berbagai negara sering nenunjukkan perbedaan sesuai dengan situasi setempat. Indonesia selama ini menetapkan batasan penduduk usia kerja 10 tahun ke atas. Tetapi mulai Sensus Penduduk 2000, batasan penduduk usia kerja disesuaikan menjadi usia 15 tahun ke atas. Penyesuaian ini dilakukan karena adanya instruksi ILO dan juga adanya program wajib sebelajar 9 tahun sampai sekolah lanjutan menengah pertama.

\section{Angkatan Kerja}

Batasan Angkatan Kerja yang digunakan baik dalam Sensus Penduduk 1971, 1980, 1990, Survei Penduduk Antar Sensus 1985 maupun Survei Angkatan Kerja Nasional mempunyai pengertian yang sama yakni mereka yang berusia 10 tahun ke atas. Mulai Sensus 2000 batasan angkatan kerja (AK) disesuaikan menjadi 15 tahun ke atas yang kegiatan utamanya seminggu yang lalu sebelum waktu pencacahan mempunyai pekerjaan (K), atau tidak mempunyai pekerjaan tetapi sedang mencari pekerjaan atau mengharapkan dapat pekerjaan (MK).

Dari konsep di atas dapat disimpulkan bahwa angkatan kerja (labor force) adalah kelompok penduduk usia kerja yang potensial untuk bekerja. Pengertian potensial adalah kesiapan setiap orang untuk masuk di pasar kerja baik saat itu sedang bekerja maupun mencari pekerjaan. Sedangkan pengertian bekerja adalah berpartisipasi aktif dalam proses produksi barang dan jasa yang secara langsung dapat meningkatkan pendapatan keluarga, dilindungi oleh undang-undang dan dapat dipertanggungjawabkan terhadap penerimaan norma-norma sosial budaya masyarakat setempat. Dengan demikian angkatan kerja dapat diformulasikan sebagai berikut

$$
\mathrm{AK}=\mathrm{K}+\mathrm{MK}
$$

Penjumlahan angkatan kerja ini dikenal sebagai persediaan angkatan kerja (labor supply). Sedangkan penjumlahan dari mereka yang berstatus bekerja dikenal dengan kebutuhan tenaga kerja (labor demand).

\section{Bukan Angkatan Kerja}

Bukan angkatan kerja adalah penduduk usia 15 tahun ke atas dimana kegiatan utamanya selama seminggu yang lalu hanya bersekolah, QE Journal | Vol.06 - N 0.03 December 2017 - 227 
mengurus rumah tangga, menerima pensiun, tidak melakukan kegiatan yang dapat dikategorikan sebagai bekerja, sementara tidak bekerja, atau mencari pekerjaan.

Berdasarkan konsep ini berarti mereka yang bersekolah, mengurus rumah tangga yang tidak menerima upah dan kelompok yang dapat lebih diperkuat masuk dalam kelompok bukan angkatan kerja, mereka yang masuk dalam kategori ini disebut sebagai penduduk yang non aktif secara ekonomi.

\section{Tingkat Partisipasi Angkatan Kerja}

Tingkat Partisipasi Angkatan Kerja (TPAK) diperoleh dari persentase perbandingan antara penduduk bekerja dan mencari pekerjaan (AK) dengan penduduk usia kerja (TK). Tingkat partisipasi angkatan kerja ini dapat dihitung denga rumus berikut :

$$
\text { TPAK }=\frac{\text { AK }}{\text { TK }} \times 100 \%
$$

\section{Kesempatan Kerja}

Istilah kesempatan kerja mengandung pengertian lapangan pekerjaan atau kesempatan yang tersedia untuk bekerja akibat dari suatu kegiatan ekonomi (produksi). Dengan demikian pengertian kesempatan kerja adalah mencakup lapangan pekerjaan yang sudah diisi dan semua lapangan pekerjaan yang masih lowong. Mengingat data kesempatan kerja nyata sulit untuk diperoleh, maka untuk keperluan praktis digunakan pendekatan banyaknya lapangan kerja yang terisi yang tercermin dari jumlah penduduk yang bekerja (employed).

Seseorang dikategorikan bekerja apabila yang bersangkutan melakukan pekerjaan yang maksudnya memperoleh pendapatan atau keuntungan paling sedikit 1 (satu) jam dalam seminggu yang lalu (seminggu sebelum pencacahan).

\section{Pengangguran Terbuka}

Pengangguran terbuka (open unemployment) adalah penduduk usia kerja yang: (a) Belum bekerja dan sedang berusaha mendapat pekerjaan, (b) Sudah pernah bekerja karena sesuatu hal berhenti atau diberhentikan dan 
sedang berusaha memperoleh pekerjaan, (c) Dibebastugaskan baik akan dipanggil kembali atau tidak tetapi sedang berusaha untuk mendapatkan pekerjaan. Pengertian pengangguran tidak dapat disamakan dengan pencari kerja, karena seringkali terjadi diantara pencari kerja terdapat mereka yang tergolong bekerja, maupun karena berbagai alasan masih mencari pekerjaan.

Untuk mengukur pengangguran terbuka digunakan indikator tingkat pengangguran yaitu jumlah pengangguran dibagi dengan jumlah angkatan kerja yang dinyatakan dalam persen. Pengukuran tingkat pengangguran (TP) yang digunakan oleh Badan Pusat Statistik adalah rasio antara banyaknya pencari kerja (MK) dengan jumlah angkatan kerja (AK), atau :

$$
\mathrm{TP}=\frac{\mathrm{MK}}{\mathrm{AK}} \times 100 \%
$$

\section{Setengah Penganggur}

Setengah pengangguran umumnya dinyatakan dengan ukuran jam kerja. Dengan demikian dapat diasumsikan bahwa semakin banyak jam kerja yang digunakan seseorang, berarti akan semakin produktif orang tersebut. Ukuran bekerja penuh dan setengah penganggur ditetapkan berdasarkan produktifitas atau pendapatan. Berpedoman kepada ketiga kriteria ini, maka bekerja penuh dapat diartikan sebagai: setiap orang yang bekerja dan mampu memenuhi salah satu atau keseluruhan ukuran normal jam kerja, produktifitas dan/atau pendapatan. Mereka yang tidak mempenuhi standar tersebut digolongkan ke dalam kelompok setengah penganggur.

Secara lebih kongkrit setengah penganggur adalah seseorang yang bekerja dibawah 35 jam per minggu dari jam kerja normal. Dalam kelompok ini tidak dibedakan status pekerjaan seseorang, apakah orang tersebut berstatus sebagai buruh/keryawan, pekerja mandiri, pengusaha ataupun pekerja keluarga tidak dibayar. Tingkat setengah pengangguran (TSP) diperoleh melalui ratio jumlah penduduk yang termasuk dalam kelompok setengah pengangguran (SP) terhadap banyaknya penduduk yang bekerja $(\mathrm{K})$, atau:

$$
\mathrm{TSP}=\frac{\mathrm{SP}}{\mathrm{K}} \times 100 \%
$$


Pengangguran kritis adalah seseorang yang bekerja kurang dari 15 jam seminggu dan masih mencari pekerjaan lain atau masih bersedia menerima pekerjaan lain/ambahan $(\mathrm{K}<15$ jam). Tingkat pengangguran kritis dihitung melalui rasio jumlah penduduk yang bekerja kurang dari 15 jam seminggu terhadap penduduk yang bekerja $(\mathrm{K})$, atau:

$$
\mathrm{TPK}=\frac{\mathrm{K}<15 \mathrm{jam}}{\mathrm{K}} \times 100 \%
$$

\section{Pengangguran Bruto}

PengangguranBruto adalah penjumlahan pengangguran terbuka dengan setengah pengangguran.

\section{$\underline{\text { Status Pekerjaan }}$}

Status pekerjaan adalah kedudukan seseorang dalam unit usaha/kegiatan dalam melakukan kegiatan sebagai apa. Status pekerjaan dibagi ke dalam 5 (lima) kelompok, yaitu:

1. Berusaha sendiri, adalah mereka yang bekerja atas resiko sendiri tanpa bantuan orang lain.

2. Berusaha dengan dibantu oleh anggota rumah tanggaburuh tidak tetap, adalah mereka yang dalam melakukan usahanya dibantu oleh anggota rumah tangga atau buruh tidak tetap.

3. Berusaha dengan buruh tetap, adalah mereka yang melakukan usahanya dengan mempekerjakan buruh tetap yang dibayar (sering pula diartikan sebagai majikan).

4. Buruh/karyawan adalah seseorang yang bekerja pada orang lain atau instansi baik pemerintah atau swasta dengan menerima upah/gaji baik berupa uang maupun barang.

5. Pekerja keluarga, adalah anggota rumah tangga yang membantu usaha untuk memperoleh penghasilan atau keuntungan yang dilakukan oleh seorang anggota rumah tangga atau bukan anggota rumah tangga tanpa mendapat upah/gaji.

Orang yang bekerja dengan status (1), (2) dan (5) di atas seringkali digunakan sebagai pendekatan untuk memperkirakan jumlah orang yang bekerja di sektor informal; sedangkan jumlah orang yang bekerja dengan status (3) dan (4) digunakan untuk pendekatan pada sektor formal. 


\section{SIMPULAN DAN SARAN}

Selama periode 2009 - 2013, persediaan tenaga kerja di Kota Padang bertambah sebesar 7.833 orang, atau naik rata-rata sekitar 0,55 perser per tahun. Angkatan kerja umur produktif (25 - 54 tahun) jauh lebih besar dibandingkan dengan kelompok umur muda (15 - 24 tahun) dan kelompok umur tua (55 + tahun), baik di desa maupun di kota. Angkatan kerja lakilaki meningkat lebih cepat dari pada angkatan kerja wanita. Selama kurun waktu 2009 - 2013 angkatan kerja laki-laki bertambah sebesar 6.924 orang atau naik sekitar 0,75 persen per tahun. Sedangkan angkatan kerja wanita bertambah sebesar 909 orang, dengan laju pertumbuhan sebesar 0,18 persen per tahun.

Dari segi pendidikan terlihat bahwa kualitas angkatan kerja di Kota Padang semakin meningkat. Selama periode 2012- 2013 telah terjadi penurunan proporsi angkatan kerja yang tidak pernah sekolah, tidak tamat SD dan tamat SD yang cukup berarti. Secara keseluruhan pada tahun 2012 proporsi angkatan kerja yang tidak pernah sekolah, yang tidak tamat SD dan tamat SD adalah sebesar 17,97 persen, turun menjadi sekitar 17,10 persen pada tahun 2013. Akan tetapi proporsi angkatan kerja yang berpendidikan tinggi (D-III ke atas) masih rendah. Sampai dengan tahun 2013, proporsi angkatan kerja tamat D-III ke atas masih kurang dari 7 persen.

Tingkat partisipasi angkatan kerja (TPAK) di Kota Padang memperlihatkan kecenderungan yang meningkat selama periode 2012 - 2013. Secara keseluruhan selama periode tersebut, TPAK di Kota Padang meningkat sekitar 1,74 persen. Untuk semua kelompok umur, partisipasi laki-laki jauh lebih besar dari pada wanita.

Jumlah angkatan kerja di Kota Padang pada tahun 2014 diperkirakan sebesar 365.758 orang, sedangkan pada tahun 2018 diperkirakan akan mencapai sekitar 396.850 orang. Dengan demikian selama periode 2014 2018 akan terjadi pertambahan angkatan kerja sebesar 31.092 orang, atau naik sebesar 2,06 persen per tahun. Selama periode tersebut, angkatan kerja laki-laki mengalami peningkatan rata-rata per tahun sebesar 1,73 persen, sedangkan angkatan kerja wanita naik sekitar 2,66 persen per tahun. Secara keseluruhan persediaan tenaga kerja pada periode, 2013 - 2018 didominasi oleh mereka pada kelompok umur 30 - 34 tahun. 
Diperkirakan terjadi kenaikan TPAK sebesar 1,49 persen selama periode 2014 - 2018. Untuk semua kelompok umur, TPAK wanita jauh lebih rendah dibandingkan dengan TPAK laki-laki. TPAK laki-laki dan wanita menurut kelompok umur umumnya memperlihatkan pola berbentuk huruf $\mathrm{U}$ terbaiik. Secara umum TPAK wanita meningkat sejalan dengan bertambahnya umur, dimana titik puncaknya dicapai pada kelompok umur 20-24 tahun dan kemudian menurun. Sedangkan TPAK laki-laki tetinggi dicapai pada kelompok umur 30-34 tahun.

Selama kurun waktu 2009 - 2013 terjadi kenaikan kebutuhan tenaga kerja di Kota Padang sebesar 1,10 persen per tahun. Lapangan usaha perdagangan, hotel dan restoran adalah yang terbesar dalam menyerap tenaga kerja. Pada tahun 2013 secara rata-rata untuk setiap 10 orang pekerja di Kota Padang, 3 diantaranya bekerja di lapangan usaha perdagangan, hotel dan restoran. Lapangan kerja yang terendah dalam menyerap tenaga kerja adalah listrik, gas, dan air serta pertambangan. Dalam tahun 2005, proporsi tenaga kerja yang bekerja di tiga lapangan usaha ini masih dibawah 1 persen.

Status pekerjaan utama buruh/karyawan adalah yang paling dominan di Kota Padang. Dalam tahun 2013 lebih dari 55 persen angkatan kerja bekerja dengan status buruh/karyawan. Tenaga kerja yang sebagai pekerja bebas di pertanianp proporsinya sangat kecil, kurang dari 2 persen. Tenaga kerja di Kota Padang terkonsentrasi pada profesi usaha penjualan.

Dilihat dari tingkat pendidikan, selama, periode 2009 - 2013, proporsi kebutuhan tenaga kerja di Kota Padang didominasi oleh mereka yang berpendidikan SMU ke bawah, baik tenaga kerja laki-laki maupun perempuan. Walaupun begitu, proporsi kebutuhan tenaga kerja tidak pernah sekolah dan tidak tamat SD dan tamat SD telah menurun.

Dalam tahun 2011, sekitar 21,76 persen tenaga kerja di Kota Padang mempunyai jam kerja di bawah 35 jam per minggu, naik menjadi sebesar 32,09 persen dalam tahun 2013. Proporsi tenaga kerja yang bekerja diatas 45 jam per minggu juga masih tinggi. Pada tahun 2011, sekitar 55,87 persen tenaga kerja bekerja diatas 45 jam per minggu, turun menjadi sebesar 47,36 persen dalam tahun 2013.

Empat tahun kedepan (2014 - 2018), kebutuhan tenaga kerja di Kota Padang masih didominasi oleh pekerjaan formal. Selama periode tersebut 
diperkirakan sekitar 26,77 persen tenaga kerja di daerah ini bekerja di sektor informal. Kebutuhan tenaga kerja berpendidikan rendah akan mengalami penurunan. Pada tahun 2010 tenaga kerja yang tidak sekolah, tidak tamat SD dan tamat SD diperkirakan jumlahnya makin sedikit karena adanya program wajib belajar 9 tahun. Pertambahan kebutuhan tenaga kerja sektor informal juga mengalami peningkatan, tetapi pertambahan kebutuhan tenaga kerja sektor formal masih lebih tinggi akibat pengaruh kemajuan teknologi, sistem perampingan produksi untuk meningkatkan efisiensi. Semua ini dapat menghambat pertumbuhan kebutuhan tenaga kerja di sektor informal.

Proporsi penduduk yang bekerja kurang dari 35 jam per minggu selama periode 2014 - 2018 masih tinggi. Hingga tahun 2018, tingkat setengah penganggur mencapai sebesar 17 persen dari keseluruhan penduduk bekerja. Kebutuhan tenaga kerja yang berpendidikan rendah terus mengalami penurunan, dan sebaliknya kebutuhan tenaga kerja yang berpendidikan SMTA ke atas terus mengalami peningkatan.

Tingkat pengangguran terbuka di Kota Padang mengalami penurunan selama periode 2009-2013. Tingkat pengangguran terbuka untuk tenaga kerja wanita lebih tinggi dari tenaga kerja laki-laki dan tingkat pengangguran terbuka didaerah pedesaan jauh lebih tinggi dari daerah kota. Tingkat pengangguran terbuka bagi tenaga kerja berpendidikan tinggi jauh lebih tinggi dari kelompok berpendidikan lainnya.

Tingkat setengah pengangguran lebih tinggi pada tenaga kerja laki-laki dari pada tenaga kerja wanita. Tingkat setengah pengangguran kritis tenaga kerja laki-laki lebih tinggi dari wanita untuk hampir semua periode.

Masalah ketenagakerjaan yang krusial di Kota Padang selama periode 2009 - 2013 adalah pengangguran terbuka, setengah pengangguran, dan pengangguran kritis. Masalah pengangguran ini semakin berat karena semakin terintegrasinya pasar tenaga kerja dengan daerah lain. Kunci utama mengatasi masalah pengangguran ini adalah pertumbuhan ekonomi, terutama untuk sektor industri. Untuk mendorong pertumbuhan ekonomi, pemerintah daerah Kota Padang perlu meningkatkan kerjasama dengan pihak swasta dan luar negeri.

Perluasan kesempatan kerja tidak terlepas dari pengembangan industri pengolahan. Untuk itu, perlu mengidentifikasi produk olahan dari QE J ournal | Vol.06 - N o. 03 December 2017 - 233 
komoditas unggulan. Identifikasi produk olahan ini hendaknya melahirkan beberapa industri yang kemudian akan membutuhkan tenaga kerja untuk pengolahannya. Dalam kaitan ini, perlu ditentukan kebutuhan akan skill pekerja yang akan mengolah bahan baku menjadi bahan setengah jadi atau bahan jadi.

Masalah setengah pengangguran umumnya terkonsentrasi di daerah kota. Oleh karena itu, perlu diidentifikasi penyebab utama setengah pengangguran tersebut. Kemudian baru dirumuskan kebijakan untuk menciptakan lapangan kerja alternatif bagi tenaga kerja setengah menganggur tersebut, sehingga waktu yang tersedia dalam satu hari dapat digunakan untuk kegiatan yang produktif.

Untuk memperluas kesempatan kerja, perlu didorong pengembangan usaha kecil dan menengah. Kebijakan yang perlu ditempuh adalah mengurangi kendala untuk tumbuh dan berkembangnya usaha kecil dan menegah tersebut. Salah satu upaya yang dapat dilakukan adalah memberikan kesempatan penambahan modal usaha untuk mempermudah proses pemberian kredit perlu dilakukan sehingga usaha ini secara cepat dan mudah menghasilkan kegiatan-kegiatan usaha baru. Perlu ada sebuah institusi yang dapat menjembatani perbankan dengan usaha kecil dan menengah dalam mendapatkan pinjaman dengan tingkat bunga yang rendah. Selain itu, institusi ini dapat pula memberikan bimbingan yang berkelanjutan terhadap pengusaha kecil dan menengah.

Usaha untuk memperluas kesempatan kerja dapat pula dilakukan dengan mendorong pengembangan usaha informal untuk memasok kebutuhan makanan, minuman perdagangan eceran untuk kebutuhan karyawan instansi pemerintah dan swasta. Pemerintah juga perlu menerapkan konsep perluasan kesempatan kerja off-farm, off-service, disamping memperkenalkan usaha sampingan untuk keluarga petani.

Untuk menunjang pertumbuhan kesempatan kerjasama dengan pihak luar, perlu ditingkatkan program kerjasama dengan perguruan tinggi untuk menganalisis dan menyusun program ketenagakerjaan daerah. Disamping itu, yang tidak kalah pentingnya adalah peningkatan kualitas SDM jajaran Dinas Tenaga kerja sendiri dan instansi yang mempunyai kaitan dengan ketenagakerjaan, sehingga muncul aparat yang mampu menangkap dan mengatasi permasalahan ketenagakerjaan daerah yang semakin rumit. 


\section{DAFTAR PUSTAKA}

Badan Pusat Statistik (2009), Survey Angkatan Kerja Nasional Kota Padang, Badan Pusat Statistik, Padang.

----- ----- (2010), Survey Angkatan Kerja Nasional Kota Padang, Badan Pusat Statistik, Padang.

----- ----- ----- (2011), Survey Angkatan Kerja Nasional Kota Padang, Badan Pusat Statistik, Padang.

--a---- (2012), Survey Angkatan Kerja Nasional Kota Padang, Badan Pusat Statistik, Padang.

----- ----- ----- (2013), Survey Angkatan Kerja Nasional Kota Padang, Badan Pusat Statistik, Padang.

--ad (2009), Padang Dalam Angka, Badan Pusat Statistik, Padang.

--o10), Padang Dalam Angka, Badan Pusat Statistik, Padang.

(2011), Padang Dalam Angka, Badan Pusat Statistik, Padang.

----- (2012), Padang Dalam Angka, Badan Pusat Statistik, Padang.

-a-co (2013), Padang Dalam Angka, Badan Pusat Statistik, Padang.

Departemen Tenaga Kerja (1996), Situasi Tenaga Kerja dan Kesempatan Kerja di Indonesia 1995, Departemen Tenaga Kerja, Jakarta.

Manning, Chris (1982), Kegiatan Ekonomi Angkatan Kerja di Indanesfa: Sebuah Pengantar Analisis dan Interpretasi Data Sensus, Pusat Studi Kependudukan Universitas Gadjah Mada, Seri Kertas Kerja Proyek Dinamika Kependudukan No. 20, Yogyakarta.

Pollard, A. H., dan Kawan-kawan (1975), Demographic Techniques, Pergamon Press, Australia. 
Sofyardi (1997), Perkembangan Persediaan Tenaga Kerja Sumatera Barat dan Perkiraan Menyongsong Repelita VII, Jurnal Penelitian Andalas, No. 25 /September/Tahun IX: 51 - 73.

Syahruddin dan Kawan-kawan (1996), Perencanaan Kesempatan Kerja Repelita VII Sumatera Barat, Kerjasama Kantor Wilayah Departemen Tenaga Kerja Propinsi Sumatera Barat dengan Pusat Studi Kependudukan Universitas Andalas, Padang.

--------(1998), Identiffikasi Pengangguran Daerah Tingkat II di Sumatera Barat, Kerjasama Kantor Wilayah Departemen Tenaga Kerja Propinsi Sumatera Barat dengan Pusat Studi. Kependudukan Universitas Andalas, Padang.

Todaro, M. dan T. Shikind (1981), City Bias and Rural Neglect The Dilemma of Urban Development, The Population Council, New York.

United Nations (1971), Manual V. Methods of Projecting the Population, population Population Studies, No. 46 United Nations, New York.

Widarti, Diah (1986), Angkatan Kerja di Indonesia: Hasil Senses Penduduk 1980, dalam Kartomo, Wirosuhardio (Ed.), Kebijaksanaan Kependudukan dan Ketenagakerjaan di Indonesia, Lembaga Penerbit Fakultas Ekonomi Universitas Indonesia, Jakarta. 